\title{
PENERAPAN PEMBELAJARAN METODE DISKUSI UNTUK MENINGKATKAN HASIL BELAJAR MATEMATIKA MAHASISWA PADA MATERI DETERMINAN \\ Mahsup*, Abdillah, Syaharuddin
}

Pendidikan Matematika, Universitas Muhammadiyah Mataram, supyeka@gmail.com

\begin{tabular}{l} 
INFO ARTIKEL \\
\hline Riwayat Artikel: \\
Diterima: 12-01-2019 \\
Disetujui: 21-01-2019
\end{tabular}

Kata Kunci:

Model Pembelajaran diskusi

Hasil Belajar

\section{A. LATAR BELAKANG}

Matematika secara garis besar dibagi ke dalam 4 cabang yaitu aritmetika, aljabar, geometri, dan analisis (Bell, 1978:27). Aljabar merupakan cabang matematika yang menempati posisi penting untuk dipelajari karena Aljabar digunakan oleh setiap orang dalam kehidupan sehari-hari. Aljabar mempunyai peran utama dalam mempelajari cabang matematika yang lain dan menyediakan sarana yang dapat digunakan untuk mempermudah memecahkan masalah misalnya, sistem koordinat, vektor, dan transformasi.

Hadiwidjoyo (1993:457) mengatakan bahwa pelajaran aljabar penting diajarkan diperguruan tinggi. Ada empat alasan mengapa perlu geometri. Pertama, aljabar adalah cabang matematika yang mempelajari pola-pola visual. Kedua, aljabar adalah cabang matematika yang menghubungkan matematika dengan dunia fisik atau dunia nyata. Ketiga, aljabar adalah suatu cara penyajian fenomena yang tidak tampak atau tidak bersifat fisik. Keempat, aljabar adalah suatu contoh sistem matematika.

Pada dasarnya aljabar mempunyai peluang yang lebih besar untuk dipahami mahasiswa daripada cabang matematika yang lain, karena ide-ide aljabar sudah dikenal mahasiswa sejak sebelum masuk pergurun tinggi. Dengan demikian, aljabar merupakan cabang matematika yang sudah akrab dengan mahasiswa dan mempunyai peluang lebih besar untuk dipahami. Namun kenyataan menunjukkan bahwa masih banyak mahasiswa yang sulit belajar aljabar. Sebagian besar mahasiswa masih mengalami kesulitan untuk 
memahami konsep-konsep aljabar. Secara umum pemahaman mahasiswa masih kurang pada konsep aljabar, unsur-unsur aljabar, struktur aljabar dan logika penalarannya.

Berdasarkan hasil pengamatan sebagai dosen pada semester III pada mahasiswa di prodi Pendididkan diketahui bahwa materi determinan merupakan materi yang dianggap sulit oleh mahasiswa. Selain itu, sebagian besar mahasiswa masih kurang mampu menterjemahkan soal-soal yang berbentuk cerita ke dalam simbol matematika. Jadi diduga bahwa pemahaman mahasiswa masih kurang memadai. Dimana mahasiswa mengalami kesulitan dalam memahami dan menterjemahkan maksud soal ke dalam simbol matematika akibatnya mahasiswa tidak mampu menyelesaikan soal tersebut.

Selain itu mahasiswa juga masih pasif dalam proses diskusi dikelas, sehingga kemampuan dalam memahami materi yang diajarkan belum bisa diterima dan dipahami dengan baik. Untuk itu dalam proses belajar mengajar dosen sangat diperlukan untuk mengatasi kesulitan menyelesaikan soal-soal determinan. Oleh karena itu seorang dosen perlu mengetahui kesulitan mahasiswa dalam menyelesaikan soal-soal matematika. Dalam penelitian ini akan menggali proses yang menyebabkan siswa tidak aktif dalam melakukan proses diskusi faktorfaktor apa saja yang menyebabkan mahasiswa mengalami kesulitan dalam materi determinan. Dengan demikian diharapkan dosen dapat mengambil atau menentukan usaha yang tepat untuk mengatasi masalah tersebut demi perbaikan dalam pembelajaran matematika.

Memulai pembelajaran dengan melibatkan mahasiswa secara aktif dalam menemukan konsepkonsep, struktur-struktur sampai kepada teorema atau rumus-rumus merupakan ciri dari pembelajaran dengan model pembelajaran diskusi. Model pembelajaran diskusi mempunyai prinsip aktivitas (doing) konstruksivis, realitas yaitu kebermaknaan proses aplikasi, pemahaman yaitu menemukan informal dalam konteks melalui refleksi, informal ke formal. Inter-twinment (keterkaitan intekoneksi antar konsep), interaksi (pembelajaran sebagai aktivitas sosial, sharing), dan bimbingan (dari guru dalam penemuan) juga menjadi prinsip dalam model pembelajaran diskusi ini.

Adapun kelebihan Model Pembelajaan Diskusi yaitu : (1) diskusi melibatkan semua siswa secara langsung dalam KBM (kegiatan belajar mengajar). (2) diskusi dapat merangsang peserta didik untuk lebih kreatif, khususnya dalam memberikan gagasan dan ideide. (3) dapat melatih untuk membiasakan diri bertukar pikiran dalam mengatasi setiap permasalahan. (4) diskusi dapat memperluas pengetahuan siswa. (5) diskusi dapat melatih peserta didik untuk menghargai pendapat orang lain. (6) diskusi dapat menumbuhkan dan mengembangkan cara berfikir kritis siswa. (7) dengan mengajukan dan mempertahankan pendapatnya dalam diskusi diharapkan para siswa akan dapat memperoleh kepercayaan akan kemampuan diri sendiri. (8) diskusi dapat menunjang usaha-usaha pengembangan sikap sosialisasi para siswa.

Berdasarkan uraian di atas, dapat disimpulkan bahwa penerapan model pembelajaran diskusi untuk mempelajari materi Determinan sangat diperlukan. Model pembelajaran diskusi akan memberi kebebasan kepada mahasiswa untuk mengembangkan cara berpikirnya dan dapat membuat mahasiswa mengetahui kemampuannya sendiri.

\section{Tujuan Penelitian}

Tujuan penelitian adalah "mendeskripsikan pembelajaran dengan menerapkan model pembelajaran diskusi sebagai upaya untuk meningkatkan pemahaman pada materi diskusi mahasiswa semester III Pendidikan Matematika FKIP UM Mataram.

\section{B. METODE PENELITIAN}

\section{Pendekatan dan Jenis Penelitian}

Pendekaan yang digunakan dalam penelitian ini adalah pendekatan kualitatif, dimana Penelitian kualitatif mempunyai karakteristik antara lain: (1) latar alamiah, (2) manusia sebagai alat (instrumen), (3) metode kualitatif, (4) analisis data secara induktif, (5) lebih mementingkan proses daripada hasil, dan (6) desain yang bersifat sementara (Moleong, 2009:8-13).

Jenis Penelitian ini adalah Penelitian Tindakan Kelas (PTK) dengan mempunyai beberapa karakteristik, yaitu: (1) an inquiry of practice from within (penelitian berawal dari permasalahan praktis yang dialami oleh guru dalam melaksanakan tugas sehari-harinya sebagai pengelola pembelajaran di dalam kelas), (2) self reflective inquiry (penelitian melalui refleksi diri artinya lebih menekankan pada proses pemikiran kembali (refleksi) terhadap proses dan hasil penelitian secara berkelanjutan untuk menda- patkan penjelasan dan justifikasi tentang kemajuan, peningkatan, kemunduran, kekurang efektifan dan sebagainya dari pelaksanaan sebuah tindakan untuk dapat digunakan memperbaiki proses tindakan pada tindakan-tindakan selanjutnya), (3) fokus penelitian berupa kegiatan pembelajaran, dan (4) bertujuan untuk mem-perbaiki pembelajaran (Wardani, 2003:1.3).

\section{Prosedur Pelaksanaan Penelitian a. Pendahuluan.}

Sebelum pelaksanaan penelitian dilakukan, peneliti terlebih dahulu melakukan tes awal. Tes yang diberikan berbentuk uraian sebanyak 3 butir. Soal uraian dimaksudkan untuk menelusuri jawaban mahasiswa, kesalahan yang mungkin dilakukan mahasiswa dalam menjawab soal, langkah demi langkah. Sebelum penyusunan terlebih dahulu dibuat kisi-kisi soal. Setelah itu baru soal tes itu disusun berdasarkan kisi-kisi tersebut. Tahap-tahap yang dilaksanakan pada tahap pendahuluan meliputi Mengidentifikasi kesulitan mahasiswa.

\section{b. Pelaksanaan.}

Tahap pelaksanaan penelitian ini dibagi ke dalam 1 tindakan, Pelaksanaan tindakan dilakukan sesuai model yang dikembangkan oleh Kemmis dan Mc Taggart. Model ini meliputi tahap (a) merencanakan, (b) melaksanakan, (c) mengamati, dan (d) merefleksi yang membentuk suatu siklus (Wardani, 2003). Siklus dalam suatu tindakan akan diulang sampai kriteria yang ditetapkan dalam setiap tindakan tercapai.

Kegiatan untuk masing-masing tindakan dapat dijelaskan sebagai berikut. 
Tindakan I

1) Merencanakan (plan)

Dalam tahap ini yang dilakukan adalah: menyusun rencana pelaksanaan pembelajaran (RPP) dan menyiapkan soal tes.

2) Melaksanakan (action)

Melaksanakan tindakan disesuaikan dengan rencana pelaksanaan pembelajaran yang telah disusun,yaitu pembelajaran model pembelajaran diskusi materi determinan. Proses pembelajaran dilaksanakan dengan mempedomani rencana pembelajaran determinan yang telah disusun pada saat perencanaan tindakan.

3) Mengamati (observation)

Mengamati dilakukan selama kegiatan pelaksanaan tindakan berlangsung. Objek yang diamati meliputi aktivitas mahasiswa selama kegiatan pembelajaran berlangsung.

4) Merefleksi (reflection)

Merefleksi artinya memikirkan ulang berdasarkan rekaman, catatan, temuan, kejadian-kejadian dalam proses pembelajaran demi perbaikan dalam pembelajaran. Merefleksi dilakukan untuk melihat keseluruhan proses pelaksanaan tindakan dan hasil pemahaman mahasiswa. Merefleksi adalah menganalisis data-data yang diperoleh dari observasi, dan catatan lapangan. Tahap refleksi meliputi kegiatan memahami, menjelaskan, dan menyimpulkan data. Kriteria tindakan I dikatakan tercapai jika proses pembelajaran yaitu aktivitas dosen dan aktivitas mahasiswa berada pada katagori sangat baik atau baik., tetapi kelemahan yang terdapat pada proses tindakan I diperbaiki pada tindakan II.

\section{c. Penutup}

Data yang diperoleh dari menganalisis hasil tes pada akhir siklus pembelajaran, menganalisis hasil observasi, dan menyimpulkan keberhasilan tindakan berdasarkan hasil analisis yang dilakukan peneliti bersama dengan observer apabila mencapai keberhasilan selanjutnya membuat laporan.

\section{Data dan Sumber Data}

Data yang akan dikumpulkan dalam penelitian ini yaitu data hasil tes mahasiswa di akhir tindakan penelitian. Data yang didapatkan berupa skor. Sumber data dalam penelitian ini adalah mahasiswa semester III FKIP UM Mataram.

\section{Prosedur Pengumpulan Data}

Data yang dikumpulkan dalam penelitian ini adalah data tes akhir belajar mahasiswa. Dimana tes yang diberikan kepada mahasiswa berupa tes. Tes akhir dilakukan untuk melihat kemajuan mahasiswa dalam mengikuti pembelajaran. Tes akhir diberikan pada akhir Siklus. Tes dikatakan berhasil jika sekurang-kurangnya $85 \%$ dari keseluruhan mahasiswa mendapatkan nilai $\geq$ 65.

\section{Analisis Data}

Data tentang hasil belajar mahasiswa diperoleh dari hasil tes mahasiswa pada akhir siklus pembelajaran. Setelah hasil tes mahasiswa diperoleh, hasil tes mahasiswa diberi skor sesuai pedoman penskoran, kemudian dianalisis menggunakan rumus:

$$
S R=\frac{S}{n} x 100 \%
$$

Tes dikatakan berhasil jika sekurang-kurangnya $85 \%$ dari keseluruhan mahasiswa mendapatkan nilai $\geq 65$.

\section{HASIL PENELITIAN}

\section{Paparan Data Penelitian}

Kegiatan yang dilakukan pada pelaksanaan siklus I meliputi perencanaan, pelaksanaan, observasi dan refleksi. Masing-masing kegiatan dapat dijelaskan sebagai berikut.

\section{a. Perencanaan}

Pada siklus I, ada beberapa hal yang dilakukan peneliti, yaitu: mempersiapkan perangkat pembelajaran dan instrumen penelitian. Perangkat pembelajaran terdiri dari RP Tindakan I dan II. Instrumen penelitian terdiri dari lembar observasi kegiatan dosen dan mahasiswa.

\section{b. Pelaksanaan Tindakan}

Pelaksanaan siklus I terdiri dari pelaksanaan kegiatan pembelajaran dan pelaksanaan tes.

\section{c. Pelaksanaan Kegiatan Pembelajaran}

\section{1) Pelaksanaan Pembelajaran Pertemuan I}

Proses pembelajaran pada siklus I dilaksanakan dalam 2 kali pertemuan, masing-masing pertemuan 2 jam pelajaran yaitu $2 \times 50$ menit. Dilaksanakannya proses pembelajaran pertemuan I adalah memperhatikan cakupan materi dan indikator keberhasilan pembelajaran serta waktu yang terjadwal dalam 1 kali pertemuan. Pembelajaran dilaksanakan berdasarkan rencana pembelajaran yang telah disusun sebelumnya.

Dalam pelaksanaan pembelajaran peneliti bertindak sebagai dosen dan taman sejawat bertindak sebagai pengamat. Kegiatan pembelajaran dilaksanakan dengan 3 tahapan pembelajaran, yaitu pendahuluan, kegiatan inti, dan kegiatan penutup. Tahap pendahuluan, dosen membuka kegiatan belajar dengan memberi salam dan mengecek kehadiran mahasiswa. Selanjutnya dalam kegiatan belajar dosen memberikan penjelasan tentang pembelajaran yang akan dilaksanakan yaitu mahasiswa akan belajar determinan dengan melakukan aktivitas metode diskusi dalam belajar. Pada tahap pendahuluan pembelajaran dosen lebih banyak memberikan intervensi kepada mahasiswa, baik berupa penjelasan, permasalahan, dan pengaturan. Kegiatan pendahuluan lebih ditujukan agar mahasiswa siap untuk belajar, baik secara fisik, pengetahuan awal, motivasi belajar, maupun bagaimana mahasiswa belajar pada pertemuan tersebut.

Kegiatan inti pembelajaran dimulai dosen dengan memerintahkan mahasiswa untuk mengerjakan soal latihan pada buku paket. Selanjutnya semua mahasiswa melakukan langkah-langkah penyelesaian dengan mencermati soal latihan yang diberikan tersebut. Pada saat mahasiswa bekerja dan belajar dengan menggunakan soal latihan dosen mengamati dengan berkeliling, sambil menanyakan "Apa ada yang ditanyakan?”. Beberapa mahasiswa mengajukan pertanyaan ketika mereka bingung untuk mengerjakan dan dosen memberikan arahan secukupnya sehingga mahasiswa tersebut dapat melanjutkan bekerja. Ada juga mahasiswa yang baru mengerjakan satu nomor tugas menanyakan kepada dosen apakah yang mereka 
kerjakan sudah benar, dosen memberikan jawaban dan arahan secukupnya serta meminta mahasiswa tersebut melanjutkan pekerjaannya.

Pada kegiatan pembelajaran, dosen menyampaikan tujuan yang ingin dicapai yaitu setelah pembelajaran mahasiswa dapat mengenal konsep determinan. Pada kegiatan pembelajaran didiskusikan tentang determinan sudah sering dipahami mahasiswa. Pada tahap penutup pembelajaran, dosen memberikan tugas untuk dikerjakan mahasiswa di rumah. Dengan pemberian tugas rumah tersebut dosen ingin mengevaluasi apakah mahasiswa sudah dapat mencapai indikator pembelajaran yang telah ditetapkan pada rencana pembelajaran. Dosen menutup pembelajaran dengan mengucapkan salam kepada mahasiswa.

Selama pembelajaran berlangsung dosen juga melakukan penilaian proses kepada masing-masing mahasiswa, yang mencakup aspek keaktifan, kerja sama, dan ketepatan dalam melaksanakan tugas-tugas belajar. Masing-masing aspek memiliki kriteria baik, cukup, dan kurang.

\section{2) Pelaksanaan Pembelajaran Pertemuan II}

Kegiatan inti pembelajaran dimulai oleh dosen dengan menjelaskan kelanjutan konsep determinan kepada semua mahasiswa. Kemudian menerapkan meode pembelajaran diskusi dalam proses pembelajaran.

Dosen berikutnya memberi kesempatan kepada mahasiswa bekerja mengerakan soal latihan. Selanjutnya dosen meminta mahasiswa untuk berdiskusi antar teman yang berdekatan duduk dan berkelomok, membaca dengan teliti dan memahami dari setiap langkah dalam menyelesaikan perrmasalahan dalam latihan soal. Dosen juga memberi kesempatan mahasiswa untuk bertanya jika ada hal yang belum dipahami. Terlihat mahasiswa langsung bekerja sesuai intruksi dalam latihan soal dan mengikuti teori pada buku paket. Serta mahasisa tidak membuang kesempatan untuk segera menyelesaikan tugasnya. Terlihat setiap mahasiswa aktif dalam menyelesaikan tugas mereka dengan berdiskusi dengan teman sebangku.

Setelah selasai mengerjakan latihan soal, dosen bersama mahasiswa membahas soal latihan tersebut. Dosen meminta masing-masing untuk menulis hasil jawabannya dipapan tulis, kemudian dosen meminta kepada mahasiswa lain untuk menanggapai hasil jawaban yang telah ditulis. Masing-masing mahasiswa memberikan tanggapan dan membenarkan apabila jawabannya tersebut sudah benar sesuai konsep teori yang telah dibahas bersama dosen. Di kegiatan penutup pembelajaran, dosen mengarahkan mahasiswa untuk menyimpulkan materi yang telah dibahas.

\section{d. Tes Akhir Siklus I}

Setelah dua kali pertemuan pada siklus I tes hasil belajar dilakukan dengan instrumen tes yang telah disusun sebelumnya yaitu berupa uraian singkat. Jumlah butir soal adalah 4 butir dan harus dikerjakan semuanya oleh mahasiswa. Penskoran hasil tes mengacu pada kriteria yang telah ditetapkan dalam rencana pembelajaran.

Adapun hasil tes akhir siklus I, ada 4 mahasiswa yang mengikuti tes. Adapun hasil tes disajikan pada tabel berikut.
Tabel 1. Hasil Tes Akhir Siklus I

\begin{tabular}{|l|l|c|c|c|c|c|}
\hline \multicolumn{2}{|c|}{ No Soal } & 1 & $\mathbf{2}$ & $\mathbf{3}$ & $\mathbf{4}$ & $\begin{array}{c}\text { Jml } \\
\text { Skor }\end{array}$ \\
\hline \multicolumn{2}{|c|}{ Skor Maksimum } & $\mathbf{2 5}$ & $\mathbf{3 0}$ & $\mathbf{2 0}$ & $\mathbf{2 5}$ & $\mathbf{1 0 0}$ \\
\hline No & Nama Mhs. & \multicolumn{5}{|c|}{ Skor } \\
\hline 1 & Hardianti & 25 & O & O & o & 25 \\
\hline 2 & Novi Haerunnisa & 25 & 10 & 20 & 25 & 80 \\
\hline 3 & Faturahmah & 25 & 30 & 20 & 10 & 85 \\
4 & Kurniawanti Nefriani & 25 & O & o & o & 25 \\
\hline
\end{tabular}

Berdasarkan perolehan hasil tes di atas terlihat bahwa ada 2 mahasiswa dari 2 mahasiswa yang belum mencapai skor $\geq 65$, dan sebanyak 2 mahasiswa dari 4 mahasiswa memperoleh skor $\geq 65$ atau persentase ketuntasan belajarnya sebesar $50 \%$.

\section{e. Refleksi}

Dari tes akhir siklus diketahui bahwa prosentase mahasiswa yang memperoleh skor $\geq 65$ sebesar $50 \%$ dari keseluruhan mahasiswa yang mengikuti tes, hal ini menunjukan bahwa pembelajaran pada siklus I tidak memenuhi kriteria ketuntasan belajar yaitu paling sedikit $85 \%$ dari jumlah mahasiswa yang mengikuti tes.

Berdasarkan hasil analisa data dari uraikan di atas maka kegiatan pembelajaran pada siklus I tidak mencapai kriteria keberhasilan. Dengan demikian disimpulkan bahwa siklus I tidak memenuhi kriteria keberhasilan yang ditetapkan dalam penelitian tindakan kelas ini.

\section{TEMUAN PENELITIAN}

Temuan penelitian pada pelaksanaan tindakan dapat diuraikan sebagai berikut:

a. Perhatian mahasiswa tidak lagi terlalu terfokus pada dosen, mahasiswa sudah berani mengemukakan pendapat dan menyalahkan pendapat temannya yang tidak sesuai dengan pendapatnya.

b. Pada pertemuan II, waktu yang digunakan dalam belajar lebih mendekati pengaturan waktu direncanakan. Hal ini dapat terjadi karena mahasiswa sudah mulai terbiasa belajar dengan saling berinteraksi.

c. Pada materi determinan dengan pembelajaran metode diskusi mahasiswa dan dosen lebih aktif, tujuan pembelajaran dapat dicapai secara efektif sehingga mahasiswa dalam belajar terlihat lebih baik dari pembelajaran sebelumnya.

\section{E. KESIMPULAN DAN SARAN}

\section{Kesimpulan}

Berdasarkan paparan data dan pembahasan, dapat disimpulkan bahwa pembelajaran dengan metode diskusi pada konsep determinan tidak dapat meningkatkan hasil belajar pada mahasiswa semester III yaitu berdasarkan hasil tes akhir siklus I diketahui bahwa telah mencapai ketuntasan belajar secara kelasikal, dimana persentase pencapaian sebesar 50\% dari standar yang telah ditetapkan sebesar $85 \%$.

\section{Saran}

Berdasarkan hasil penelitian dan temuan penelitian, maka disarankan kepada pengajar untuk menggunakan pembelajaran metode diskusi dalam pembelajaran matematika di kelas, dengan memperhatikan beberapa hal berikut. 


\begin{tabular}{|c|c|}
\hline Aspek & Saran \\
\hline Proses & $\begin{array}{llr}\text { Hendaknya } & \text { lebih } & \text { memberikan } \\
\text { kesempatan } & \text { kepada } & \text { mahasiswa } \\
\text { berinteraksi } & \text { dalam } & \text { belajar } \\
\text { matematika } & & \end{array}$ \\
\hline Pengembangan & $\begin{array}{l}\text { Hendaknya dapat melakukan } \\
\text { penelitian lebih lanjut tentang } \\
\text { interaksi dan penggunaan model bagi } \\
\text { mahasiswa dalam belajar } \\
\text { matematika, sehingga peningkatan } \\
\text { kualitas belajar matematika dapat } \\
\text { terlaksana secara berkesinambungan. }\end{array}$ \\
\hline Pro & $\begin{array}{l}\text { Memperhatikan judul penelitian ini, } \\
\text { penelitian ini merupakan penelitian } \\
\text { tindakan kelas, bukan penelitian } \\
\text { pengembangan karena penelitian } \\
\text { tindakan kelas berangkat dari } \\
\text { permasalahan praktis yang ada di } \\
\text { kelas. Dimana desain yang dirancang } \\
\text { untuk mengatasi permasalahan yang } \\
\text { ditemukan dalam kelas. }\end{array}$ \\
\hline
\end{tabular}

\section{DAFTAR RUJUKAN}

[1] Bell, F.H.. 1978. Teching Learning Mathematics: In Secondary Shooles. Iowa: Wn. C. Brown Company Publishers.

[2] Clements, D.H \& Battista, M.T. 2001. Constructivist

[3] Hudojo, H.. 2005. Kapita Selekta Pembelajaran Matematika. Malang: PPS UM.

[4] Hudojo, H.. 2003. Pengembangan Kurikulum dan Pembelajaran Matematika. Malang: FPMIPA Universitas Negeri Malang.

[5] Muhsetyo, G. 1999. Metode penemuan Dalam Pembelajaran Persamaan Linier Dua Variabel. Jurnal jurusan pendidikan matematika FMIPA IKIP Malang: $73-82$

[6] Soedjadi, R. 1999. Kiat Pendidikan Matematika di Indonesia. Konstatasi Keadaan Masa Kini Menuju Harapan Masa Depan. Jakarta: Depdiknas

[7] Yuwono, I. 1992. Pengantar Analisis Real (penyunting Purwanto). Departemen Pendidikan dan Kebudayaan IKIP Malang: Proyek Operasi dan Perawatan Fasilitas. 